\title{
ACTIVITY BASED COSTING (ABC) PADA INSTITUSI PENDIDIKAN TINGGI (STUDI PADA PTS DI SULAWESI TENGAH)
}

\author{
Kisman Lantang1, Gusstiawan Raimanu² \\ ${ }^{1}$ Jurusan Manajemen, Universitas Sintuwu Maroso \\ Email:kisman@unsimar.ac.id \\ 2 Jurusan Manajemen, Universitas Sintuwu Maroso \\ Email: g.raimanu@unsimar.ac.id
}

Masuk : 04-07-2020, revisi: 20-08-2020, diterima untuk diterbitkan :07-09-2020

\begin{abstract}
ABSTRAK
Penelitian ini bertujuan untuk menganalisis perhitungan beban pokok penyelenggaraan pendidikan di Universitas Sintuwu Maroso, salah satu Perguruan Tinggi Swasta di Sulawesi Tengah melalui penerapan metode sistem akuntansi manajemen kontemporer Activity Based Costing (ABC). Penelitian ini merupakan penelitian deskriptif dengan pendekatan studi kasus. Data dikumpulkan melalui wawancara, observasi dan analisis dokumen universitas terkait dengan penelitian. Data tersebut kemudian dianalisis dengan menggunakan metode ABC yang diawali dengan peninjauan sistem manajemen keuangan perguruan tinggi, identifikasi proses bisnis dan aktivitas, identifikasi cost component, penentuan cost driver, dan mengalokasikan institution overhead cost ke masing-masing aktivitas serta menghitung besarnya total cost dan variansi biaya antara metode existing terhadap metode ABC. Hasil penelitian menunjukkan bahwa ABC mampu diimplementasikan pada perguruan tinggi melalui pengalokasian biaya aktivitas pada masing-masing program studi secara tepat berdasarkan konsumsi masing-masing aktivitas serta dapat meningkatkan keakuratan perhitungan beban pokok per semester masing-masing program studi dengan terdeteksinya distorsi biaya berupa over/under costing dari metode yang diterapkan selama ini.
\end{abstract}

Kata Kunci: Activity Based Costing, Beban Pokok Penyelenggaraan Pendidikan dan Sistem Biaya Konvensional.

\section{ABSTRACT}

The study aims to analiyze the educational cost unit calculation in Universitas Sintuwu Maroso, one of the Private University (PTS) in Central Sulawesi by implementing the contemporary management accounting system through Activity-Based Costing ( $A B C)$ method. The study is descriptive with case study approach. Data is collected through interviews, observation and university's documentation analysis that related to the study. The data then analyzed with $A B C$ Method, which starts with a review of financial management system, identify cost components, determine cost driver, allocate the institution overhead cost on each activities, and calculate the total cost and cost variance between the existing method and ABC Method. The result indicates that the ABC method has accurately allocated activity cost in each study program based on the cost of each activity and also improves the accuracy of educational cost unit calculation per semester due its ability to detect cost distortion in the form of over/under costing from the existing method.

Keywords: Activity-Based Costing, Educational Cost Unit and Conventional Costing System.

\section{PENDAHULUAN}

\section{Latar Belakang}

Perkembangan ilmu pengetahuan dan teknologi yang semakin cepat saat ini turut meningkatkan motivasi masyarakat akan kebutuhan pendidikan khususnya pendidikan tinggi. Sebab perguruan tinggi dipandang sebagai sebuah institusi yang dapat mendidik dan melatih seseorang menjadi sumber daya manusia yang unggul dan memiliki peluang untuk meraih jenjang karier yang lebih baik serta dapat bersaing dalam era yang semakin kompetitif ini. Setelah 75 tahun merdeka Indonesia kini memiliki 431 Perguruan Tinggi Negeri (PTN) dan 4.222 Perguruan Tinggi Swasta (PTS) khususnya untuk Provinsi Sulawesi Tengah terdapat 9 PTN dan 45 PTS sebagai pilihan masyarakat mengakses pendidikan tinggi (PDDIKTI Kemdikbud, 2020). Apabila dipandang dari perspektif penyelenggara institusi pendidikan tinggi keadaan ini akan meningkatkan persaingan yang luar biasa ketat terutama dalam memperoleh calon mahasiswa. 
Akibat adanya persaingan tersebut, pengelolaan keuangan menjadi isu kritis dalam mewujudkan pelayanan pendidikan yang berkualitas. Kamars (1989) dalam (Esti, 2007) menegaskan bahwa keadaan keuangan suatu perguruan tinggi merupakan ukuran utama keberhasilan dalam kualitas lulusan. Tanpa dukungan keuangan yang memadai suatu perguruan tinggi hanya akan menghasilkan manusia-manusia yang tidak percaya pada dirinya dan tidak memiliki sifat-sifat sebagaimana seharusnya seorang ilmuwan.

Mengingat begitu pentingnya peranan komponen biaya pendidikan ini maka diperlukan perhitungan yang cermat terkait dengan penentuan berapa besar biaya yang harus dibebankan kepada mahasiswa atas jasa layanan pendidikan yang dikonsumsi. Hal ini dimaksudkan agar keputusan yang diambil oleh perguruan tinggi merupakan keputusan yang tepat serta tidak melemahkan keunggulan bersaing perguruan tinggi dalam hal penerimaan mahasiswa baru karena biaya yang ditetapkan terlampau tinggi, atau justru terlalu rendah daripada yang seharusnya dibebankan.

Tujuan tersebut memerlukan kajian mengenai penggunaan biaya pada aktivitas pendidikan masing-masing program studi perguruan tinggi sebagai activity centre. Metode akuntansi biaya kontemporer yakni Activity Based Costing (ABC) dipandang mampu untuk meningkatkan keakuratan perhitungan beban pokok penyelenggaraan pendidikan sebab ABC mendasarkan pembebanan biaya pada aktivitas pendidikan dan sumber daya yang dikonsumsi (Mulyadi, 2007). Aktivitas yang dimaksud yakni bukan hanya aktivitas yang berkaitan langsung dengan pendidikan namun juga yang bersifat sebagai pendukung pendidikan dan non pendidikan.

Pada dasarnya metode Activity Based Costing (ABC) berfokus pada aktivitas-aktivitas yang tidak terlihat melalui analisis akuntansi tradisional. Metode ABC dapat mengendalikan biaya melalui penyediaan informasi tentang aktivitas yang menjadi penyebab timbulnya biaya. Metode ini memiliki dasar pemikiran bahwa biaya ada penyebabnya dan penyebab biaya adalah aktivitas. Penyebab biaya tersebut (aktivitas) dapat dikelola (Mulyadi, 2001). ABC adalah sistem akuntansi yang terfokus pada aktivitas-aktivitas yang dilakukan untuk menghasilkan produk atau jasa (Islahuzzaman, 2011). ABC juga merupakan sistem pengkalkulasian biaya, pengembangan anggaran, pengukuran kinerja dan penilaian persediaan (O'Guin, 1991). Siregar, (2013) menjelaskan bahwa $\mathrm{ABC}$ adalah suatu pendekatan perhitungan biaya yang membebankan biaya sumber daya ke dalam objek biaya. Objek biaya (cost object) adalah unsur berupa apapun yang kepadanya biaya dibebankan. Cost object juga merupakan objek yang dibiayai oleh organisasi sesuai peran keberadaannya, dapat berupa produk jadi, proses maupun jasa pelayanan yang disediakan oleh suatu perusahaan untuk konsumen (Binawati, 2011).

Bagi perguruan tinggi, metode $\mathrm{ABC}$ merupakan salah satu alternatif penting bagi pengelola perguruan tinggi dalam pertimbangannya menjadi lebih kompetitif (Ismail, 2010). Krishnan (2006) menjelaskan bahwa konsep akuntansi manajemen dan biaya tidak hanya digunakan dalam sektor manufaktur namun juga digunakan pada sektor jasa untuk menyediakan informasi biaya guna pengambilan keputusan. Cooper dan Kaplan (1991) menjelaskan bahwa perusahaan jasa dapat memperoleh keuntungan melalui penggunaan ABC karena mereka memiliki isu yang sama dengan perusahaan manufaktur seperti analisis biaya operasi dan kegiatan pelayanan yang menuntut sumber daya (Knock, 1995 dalam Krishan, 2006).

Perguruan Tinggi sebagai salah satu faktor utama pendorong kemajuan suatu bangsa dalam menghasilkan human capital yang unggul dan berdaya saing, menghasilkan riset-riset unggulan dan inovasi di bidang teknologi, memerlukan biaya investasi yang cukup besar terutama dalam 
pengembangan ICT seperti e-learning serta sistem informasi yang terintegrasi. Hal-hal ini akan mengakibatkan meningkatnya biaya dalam pendidikan tinggi. Oleh karena itu, pihak manajemen perguruan tinggi memerlukan informasi manajemen biaya yang tepat untuk menghasilkan nilai bagi institusinya.

Sejumlah penelitian menunjukkan ketermungkinan implementasi pada institusi pendidikan tinggi dan menemukan bahwa metode $\mathrm{ABC}$ mampu mengalokasikan sumber daya dan pengetatan manajemen keuangan (Ismail, 2010). Bahkan Duron (2001) menyebutkan bahwa manajemen biaya tradisional yang diterapkan pada berbagai institusi perguruan tinggi saat ini sudah tidak relevan dengan perkembangan dan perubahan lingkungan organisasi pendidikan tinggi karena menghasilkan perhitungan biaya yang kurang akurat sehingga melemahkan peran informasi biaya dalam pengambilan keputusan organisasi.

Universitas Sintuwu Maroso selama ini masih menerapkan sistem manajemen biaya tradisional dalam memutuskan kebijakan-kebijakan strategisnya terutama mengenai biaya pendidikan yang harus dibebankan kepada mahasiswa. Sebagai PTS yang masih mengandalkan pendanaan operasional selama ini sebagian besar berasal dari mahasiswa, dikhawatirkan proses penetapan tarif pendidikan yang selama ini telah dilakukan akan menyebabkan timbulnya distorsi yaitu ketidakakuratan dalam pembebanan biaya yang pada akhirnya akan mengakibatkan kesalahan dalam penentuan biaya pendidikan, pembuatan keputusan, perencanaan dan pengendalian.

Distrorsi ini pula dapat menyebabkan undercost / overcost terhadap penetapan tarif pendidikan di Universitas Sintuwu Maroso sehingga dikhawatirkan penetapannya dapat lebih tinggi maupun lebih rendah daripada yang seharusnya serta dapat mengakibatkan berkurangnya minat calon mahasiswa untuk melanjutkan studi di universitas ini. Oleh karena itu, tujuan dari penelitian ini adalah melakukan analisis atas beban pokok penyelenggaraan pendidikan pada Institusi Perguruan Tinggi Swasta (PTS) di Sulawesi Tengah khususnya Universitas Sintuwu Maroso dengan menggunakan metode $\mathrm{ABC}$ serta menganalisis sejauh mana penerapan metode $\mathrm{ABC}$ dapat meningkatkan keakuratan perhitungan beban pokok masing-masing program studi.

Implementasi $\mathrm{ABC}$ pada institusi pendidikan tinggi diharapkan dapat menghasilkan informasi biaya yang lebih akurat dan akuntabel. Selain diharapkan dapat memberikan masukan dan menjadi panduan bagi lembaga terkait dalam melakukan implementasi dan perhitungan beban pokok dengan $\mathrm{ABC}$, penelitian ini pula diharapkan dapat memberikan kontribusi bagi literatur di Indonesia secara khusus mengenai implementasi $\mathrm{ABC}$ pada institusi perguruan tinggi swasta (PTS) yang masih relatif terbatas.

\section{METODE PENELITIAN}

Penelitian ini merupakan penelitian deskriptif dengan pendekatan studi kasus yaitu penelitian tentang subjek penelitian yang berkenaan dengan suatu fase spesifik atau khas dari keseluruhan personalitas (Maxfied dalam Nazir, 2005). Penelitian ini dilakukan pada salah satu PTS di Sulawesi Tengah yakni Universitas Sintuwu Maroso (Unsimar) yang berlokasi di Jl. P. Timor No. 1 Kabupaten Poso, Sulawesi Tengah. Perguruan tinggi ini termasuk salah satu Perguruan Tinggi Swasta (PTS) yang cukup besar di Sulawesi Tengah yang memiliki enam fakultas dan delapan program sarjana. Namun dalam perkembangannya selama ini pihak manajemen perguruan tinggi belum pernah melakukan analisis beban pokok penyelenggaraan pendidikan menggunakan metode Activity Based Costing (ABC) karena masih menggunakan sistem kalkulasi biaya secara tradisional. 
Penelitian ini menggunakan kombinasi dua jenis data yaitu data primer dan data sekunder. Hal ini dikarenakan kedua jenis data tersebut akan digunakan secara bersamaan dalam membentuk biaya pokok penyelenggaraan pendidikan. Data yang digunakan dalam penelitian ini adalah dokumen-dokumen perguruan tinggi yang meliputi laporan keuangan universitas, rencana dan realisasi anggaran tahun 2018 dan dokumen hasil wawancara dengan unsur pimpinan dan bagian keuangan universitas.

Data yang telah dikumpulkan selanjutnya dianalisis dengan menggunakan metode Activity Based Costing yang diusulkan oleh Roztocki (1999). Olehnya dilakukan analisis data atas instrumen penelitian sebagai berikut:

1. Tahap Perancangan Model ABC

a. Identifikasi proses bisnis Perguruan Tinggi.

b. Review data keuangan perguruan tinggi, untuk mengetahui mata anggaran yang ada serta batasan penggunaannya.

c. Mengidentifikasi dan membuat definisi aktivitas-aktivitas utama yang dilakukan oleh jurusan, fakultas dan universitas.

d. Mengidentifikasi dan menetapkan Cost Object, Direct Labor Cost, Direct Material Cost dan Overhead Cost.

e. Identifikasi Expense Category, Cost Driver, dan Cost Component.

f. Penyusunan hirarki alokasi activity overhead cost pada tingkat fakultas dan universitas.

Untuk menentukan/mengestimasi proporsi biaya yang diserap, yaitu melalui proporsi yang besarnya ditentukan oleh cost driver yang telah diidentifikasi.

2. Tahap Penerapan Metode ABC

a. Merekonstruksi aktivitas setiap program studi berdasarkan activity dictionary pada tahun anggaran 2018-2019.

b. Mengalokasikan activity cost sesuai model ABC yang telah dibuat.

c. Perhitungan variansi (distorsi) biaya antara biaya pada kondisi pendekatan akuntansi biaya tradisional (existing) terhadap biaya dari hasil perhitungan ABC.

\section{HASIL DAN PEMBAHASAN}

Perhitungan Beban Pokok (existing)

Selama ini, perguruan tinggi melakukan analisis atas beban pokok penyelenggaraan pendidikannya menggunakan pendekatan Functional Based Costing (FBC) dimana biaya-biaya yang dikeluarkan oleh activity centre menggunakan metode alokasi langsung (direct method of allocation) dengan cost driver yang sama yakni persentase jumlah mahasiswa aktif tiap program studi, tanpa mengakui adanya interaksi antar activity centre dan tanpa memperhatikan aktivitasaktivitas yang timbul baik ditingkat universitas maupun program studi. Karena data laporan keuangan tahun 2018-2019 diasumsikan mewakili 2 semester, maka perhitungan beban pokok 1 semester masing-masing program studi pada Tabel 1, dihitung dengan rumus:

(Total Cost (Direct Cost + Overhead Cost): 2)

Tabel 1. Penetapan Beban Pokok Berdasarkan Traditional Costing Sumber : Hasil Pengolahan Data

\begin{tabular}{lrrrr}
\hline \multicolumn{1}{c}{ Program Studi } & $\begin{array}{c}\text { Beban Pokok (FBC) 1 } \\
\text { Semester }\end{array}$ & Mhs Aktif & $\begin{array}{c}\text { Mhs Aktif } \\
(\%)\end{array}$ & $\begin{array}{c}\text { Beban Pokok } \\
\text { (FBC) 1 Smt per } \\
\text { Mhs }\end{array}$ \\
\hline S1 Agroteknologi & 445.193 .093 & 379 & $7,11 \%$ & 1.174 .652 \\
\hline S1 Peternakan & 221.614 .198 & 109 & $2,05 \%$ & 2.033 .158 \\
\hline S1 Manajemen & 1.416 .708 .021 & 1.437 & $26,98 \%$ & 985.879 \\
\hline S1 Pendidikan Biologi & 715.827 .020 & 800 & $15,02 \%$ & 894.784 \\
\hline
\end{tabular}




\begin{tabular}{lrrrr}
\hline \multicolumn{1}{c}{ Program Studi } & $\begin{array}{c}\text { Beban Pokok (FBC) 1 } \\
\text { Semester }\end{array}$ & Mhs Aktif & $\begin{array}{c}\text { Mhs Aktif } \\
(\%)\end{array}$ & $\begin{array}{c}\text { Beban Pokok } \\
\text { (FBC) 1 Smt per } \\
\text { Mhs }\end{array}$ \\
\hline S1 Pendidikan Bahasa Inggris & 499.084 .397 & 385 & $7,23 \%$ & 1.296 .323 \\
\hline S1 Teknik Sipil & 811.581 .820 & 796 & $14,94 \%$ & 1.019 .575 \\
\hline S1 Ilmu Hukum & 748.287 .533 & 567 & $10,64 \%$ & 1.319 .731 \\
\hline S1 Ilmu Administrasi Negara & 1.012 .743 .716 & 854 & $16,03 \%$ & 1.185 .883 \\
\hline Total & 5.871 .039 .799 & 5.327 & & 9.909 .984 \\
\hline
\end{tabular}

Selanjutnya berdasarkan tabel diatas dapat diperoleh rata-rata beban pokok semester per mahasiswa dengan membagi Total Beban Pokok Per Mahasiswa dengan Jumlah Program Studi sehingga diperoleh rata-rata beban pokok per semester sebesar Rp. 1.238.748. Di Universitas Sintuwu Maroso selama ini dikenal 2 komponen biaya pendidikan utama yakni SPP (Sumbangan Penyelenggaraan Pendidikan) yang dibayar sekali pada awal semester dan BPP (Biaya Penyelenggaraan Pendidikan) yang dibayar setiap semester. Selain itu, ada komponen biaya lainnya seperti biaya seminar proposal, seminar hasil penelitian, ujian skripsi, Kuliah Kerja Nyata, Kuliah Kerja Profesi dan Wisuda.

Penetapan besaran biaya pendidikan termasuk kenaikannya dibandingkan periode sebelumnya selama ini baik pada kelompok Eksakta (Agroteknologi, Peternakan, Teknik Sipil dan Pendidikan Biologi) maupun Non-Eksakta (Manajemen, Ilmu Administrasi Negara, Ilmu Hukum dan Pendidikan Bahasa Inggris) selain mempertimbangkan rata-rata beban pokok semester diatas, cenderung lebih didominasi oleh kebijakan pimpinan dengan dasar pertimbangan diantaranya faktor inflasi, azas kepantasan, rata-rata biaya pendidikan PTS lainnya sebagai pembanding serta jumlah mahasiswa aktif masing-masing program studi. Sehingga keputusan biaya pendidikan kelompok eksakta dan non-eksakta seringkali mengalami perbedaan yang tidak signifikan padahal kelompok eksakta membutuhkan lebih banyak aktivitas seperti praktikum laboratorium dan praktikum lapangan yang tidak dilakukan pada kelompok non-eksakta.

Pemahaman bahwa tidak semua program studi yang ada memiliki cost driver yang sama tetapi berbeda-beda dan tidak bisa diseragamkan dalam perhitungan biayanya, maka Universitas Sintuwu Maroso memerlukan metode analisis biaya yang tepat guna menghasilkan informasi biaya yang akurat berkenan dengan biaya aktivitas penyelenggaraan pendidikan selama ini. Salah satu solusi yang dapat ditawarkan untuk mencapai tujuan tersebut adalah menggunakan metode Activity Based Costing (ABC). ABC menjadikan aktivitas sebagai titik kegiatannya. ABC tidak hanya berfokus ke perhitungan cost produk/jasa, namun mencakup perspektif yang lebih luas yakni informasi tentang apa yang menyebabkan biaya-biaya meningkat atau menurun, biaya dapat ditelusuri ke masing-masing program studi. Hubungan sebab-akibat memungkinkan manajemen perguruan tinggi untuk memperbaiki ketepatan perhitungan beban pokok penyelenggaraan pendidikan yang pada akhirnya akan bermuara pada pengambilan keputusan penetapan biaya pendidikan.

\section{Implementasi ABC pada Kalkulasi Beban Pokok}

Tujuan utama penelitian ini adalah meningkatkan keakuratan perhitungan beban pokok per semester pada masing-masing program studi dengan melakukan implementasi model ABC dimana akan diketahui berapa biaya sesungguhnya yang dikonsumsi oleh masing-masing cost object. Langkah-langkah dalam penerapan metode ABC dapat digambarkan sebagai berikut: 
Langkah 1 - Identifikasi Proses Bisnis Perguruan Tinggi

Proses bisnis perguruan tinggi yang berhasil diidentifikasi pada penelitian ini mengacu pada model CIMOSA (Computer Integrated Manufacturing for Open System Architecture) (Mahani \& Nasution, 2008), yang secara garis besar dibagi menjadi 3 level yaitu managerial process, core process, dan support process.

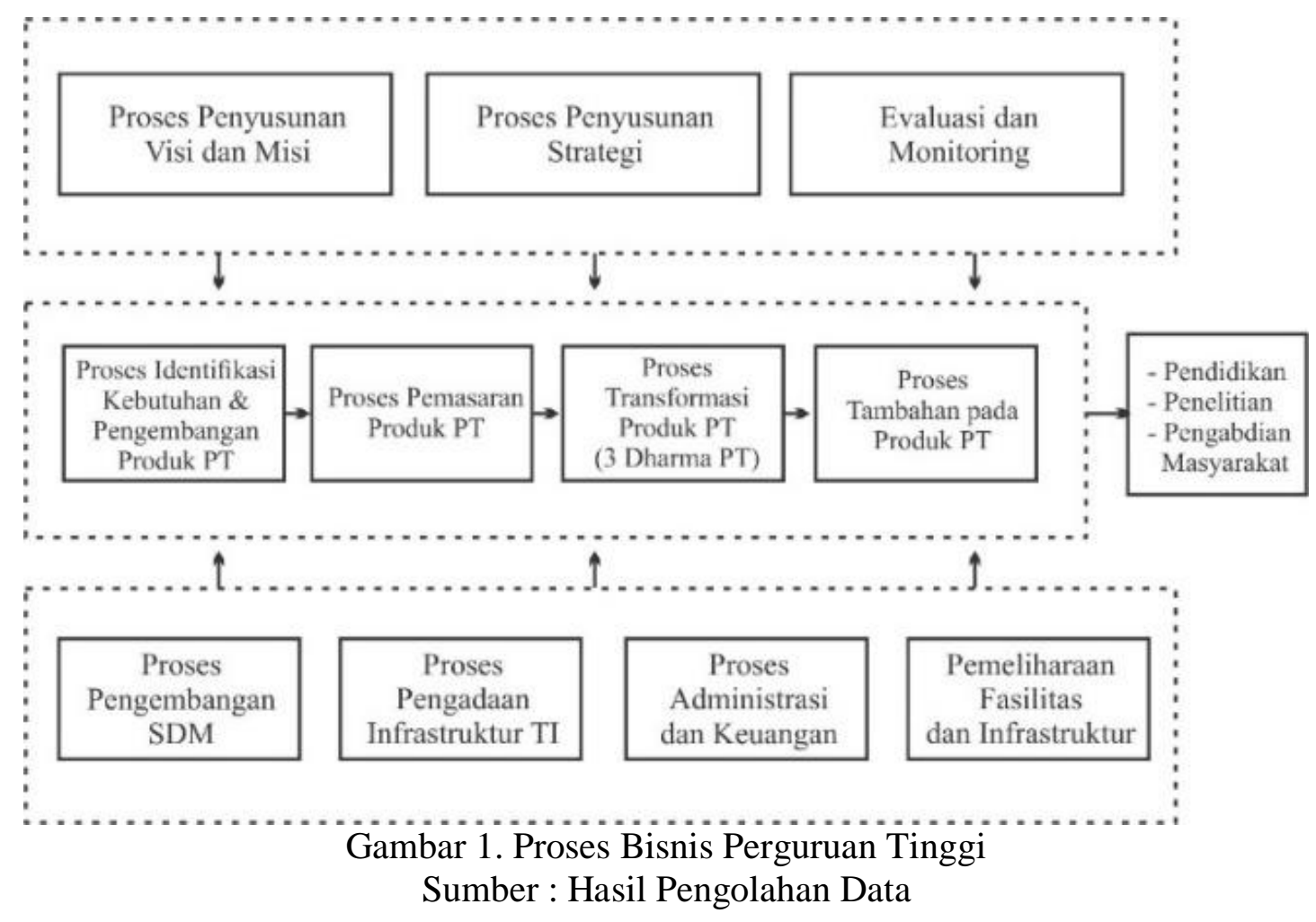

Dari flow chart proses bisnis PT tersebut, dapat diidentifikasi bahwa core process PT yang menghasilkan salah satu produk tri dharma PT yaitu pendidikan, berada di program studi sebagai pusat aktivitas belajar-mengajar.

Langkah 2 - Identifikasi Cost Object, Direct Material Cost dan Overhead Cost

Dalam penelitian ini yang dimaksud dengan cost object yaitu produk perguruan tinggi menurut tri dharma perguruan tinggi. Direct labor cost yaitu orang atau personel yang terlibat langsung dalam kegiatan pendidikan atau dalam hal ini adalah dosen. Direct material cost merupakan biaya bahan langsung yang digunakan dalam kegiatan pendidikan dapat berupa bahan habis pakai. Overhead cost yaitu biaya lain-lain selain direct labor cost dan direct material cost yang dapat ditelusuri ke produk.

\section{Identifikasi Biaya Direct Tracing}

Direct tracing merupakan pembebanan biaya langsung ke aktivitas dengan cara mengidentifikasi secara langsung konsumsi sumber daya oleh aktivitas. Identifikasi biaya langsung ini dibagi menjadi direct labor cost dan direct material cost pada level core process. Aktivitas-aktivitas ini merupakan aktivitas yang terjadi di tingkat program studi. 
Tabel 2. Direct Tracing Program Studi

Sumber : Hasil Pengolahan Data

\begin{tabular}{llll}
\hline \multirow{2}{*}{ Program Studi } & \multicolumn{3}{c}{ Realisasi Biaya Langsung } \\
\cline { 2 - 4 } & \multicolumn{1}{c}{ Direct Labor Cost $(\mathrm{Rp})$} & Direct Material Cost $(\mathrm{Rp})$ & Total Direct Cost $(\mathrm{Rp})$ \\
\hline S1 Agroteknologi & 385.461 .810 & 115.284 .964 & 500.746 .774 \\
\hline S1 Peternakan & 219.707 .180 & 98.704 .036 & 318.411 .216 \\
\hline S1 Manajemen & 739.701 .491 & 535.144 .000 & 1.274 .845 .491 \\
\hline S1 Pendidikan Biologi & 252.774 .400 & 340.040 .802 & 592.815 .202 \\
\hline S1 Pend. Bahasa Inggris & 448.819 .200 & 165.042 .966 & 619.862 .166 \\
\hline S1 Teknik Sipil & 517.889 .945 & 164.049 .500 & 681.939 .445 \\
\hline S1 Ilmu Hukum & 829.195 .776 & 101.622 .600 & 930.818 .376 \\
\hline S1 Ilmu Adm. Negara & 592.178 .547 & 251.995 .600 & 844.174 .147 \\
\hline Total & 3.985 .728 .349 & 1.771 .884 .468 & 5.757 .612 .817 \\
\hline
\end{tabular}

Penelusuran biaya langsung dengan direct tracing dapat meningkatkan akurasi biaya dan lebih sederhana, karena kategori aktivitas dan dasar alokasi biaya tidak perlu diidentifikasi seperti pada penelusuran biaya overhead. Dalam penelitian ini, aktivitas-aktivitas yang terkait dengan penyelenggaraan pendidikan diidentifikasikan menjadi direct cost. Biaya tersebut dapat ditelusuri secara langsung karena biaya pada aktivitas tersebut merupakan biaya yang dikeluarkan langsung untuk mahasiswa.

\section{Identifikasi Biaya Driver Tracing}

Driver tracing merupakan suatu pembebanan biaya tidak langsung (overhead) ke aktivitas melalui hubungan sebab akibat antara sumber daya yang dikonsumsi dengan aktivitas yang ditimbulkan. Dalam penelitian ini terlebih dahulu diidentifikasikan biaya tidak langsung pada tingkat program studi dan selanjutnya pada tingkat universitas.

Tabel 3. Realisasi Biaya Overhead Program Studi Sumber : Hasil Pengolahan Data

\begin{tabular}{lc}
\hline Program Studi & Realisasi Overhead Cost $(\mathrm{Rp})$ \\
\hline S1 Agroteknologi & 31.944 .500 \\
\hline S1 Peternakan & 21.944 .500 \\
\hline S1 Manajemen & 202.350 .000 \\
\hline S1 Pendidikan Biologi & 83.810 .000 \\
\hline S1 Pendidikan Bahasa Inggris & 20.949 .000 \\
\hline S1 Teknik Sipil & 189.970 .500 \\
\hline S1 Ilmu Hukum & 30.630 .000 \\
\hline S1 Ilmu Administrasi Negara & 375.320 .000 \\
\hline Total Biaya Overhead & 956.918 .500 \\
\hline
\end{tabular}

Langkah 3 - Identifikasi Expense Category, Cost Driver dan Cost Component Berdasarkan hasil wawancara dan analisis dokumen, hasil identifikasi expense category, cost driver dan cost component sebagai berikut:

Tabel 4. Expense Category, Cost Driver dan Cost Component tingkat Universitas Sumber : Hasil Pengolahan Data

\begin{tabular}{lcl}
\hline \multicolumn{1}{c}{ Cost Component } & Cost (Rp) & \multicolumn{1}{c}{ Cost Driver } \\
\hline Belanja Pegawai & & \\
\hline Gaji & 967.737 .650 & Jumlah Pegawai \\
\hline Insentif & 872.400 .100 & Jumlah Pegawai, Frekuensi Kegiatan \\
\hline Belanja Barang & & \\
\hline Administrasi & 181.292 .000 & Frekuensi Kegiatan \\
\hline ATK & 27.895 .300 & Jumlah Unit \\
\hline
\end{tabular}




\begin{tabular}{lrl}
\hline \multicolumn{1}{c}{ Cost Component } & Cost $(\mathrm{Rp})$ & \multicolumn{1}{c}{ Cost Driver } \\
\hline Perjalanan Dinas & 88.405 .600 & Jumlah dan Jenis Perjalanan Dinas \\
\hline Langganan Daya dan Jasa & 142.990 .539 & Jumlah dan Jenis Langganan \\
\hline Popularisasi & 79.221 .000 & Frekuensi Kegiatan \\
\hline Miscelaneous Expenses & 298.302 .742 & Tidak diketahui \\
\hline Penelitian dan Pengabdian & 89.570 .000 & Frekuensi Kegiatan \\
\hline Konsumsi & 32.589 .500 & Frekuensi Kegiatan \\
\hline Akademik & 1.833 .420 .000 & Frekuensi Kegiatan, Jumlah Mahasiswa \\
\hline Belanja Modal & & \\
\hline Alat Kantor & 135.036 .850 & Jumlah Alat \\
\hline Alat Laboratorium & 22.500 .000 & Jumlah Alat \\
\hline IT Support & 133.951 .000 & Jumlah Unit \\
\hline Koleksi Pustaka & 40.746 .000 & Jumlah Unit \\
\hline Kendaraan & 12.442 .500 & Jumlah Unit \\
\hline Pemeliharaan & 58.777 .500 & Jumlah Unit, Frekuensi Kegiatan \\
\hline Sewa & 10.270 .000 & Frekuensi Kegiatan \\
\hline
\end{tabular}

Langkah 4 - Identifikasi dan Seleksi Cost Driver

Penggerak biaya (cost driver) diidentifikasi dengan melihat apa saja yang terkait pada aktivitas. Berdasarkan data yang tersedia, pemilihan cost driver didasarkan pada prinsip kemudahan/ketersediaan data. Cost driver merupakan faktor yang dapat menerangkan konsumsi biaya-biaya overhead. Faktor ini menunjukkan suatu penyebab utama tingkat aktivitas yang akan menyebabkan biaya dalam aktivitas-aktivitas selanjutnya. Penentuan cost driver mempertimbangkan beberapa faktor di antaranya, kemudahan untuk menentukan dan memperoleh data yang diperlukan dari pemicu biaya (cost of measurement) serta korelasi antara tingkat konsumsi aktivitas dari pemicu biaya dengan konsumsi aktivitas (degree of correlation).

Langkah 5 - Menghubungkan Aktivitas dengan Biaya dalam Matriks Expenses Activity Dependance (EAD)

Matriks EAD digunakan untuk menghubungkan aktivitas dengan biaya yang dikonsumsinya. Proses ini dilakukan dengan membuat tanda centang (check marks) secara proporsional dalam matriks EAD untuk menentukan hubungan atau keterkaitan dari tiap aktivitas yang ada dalam menyerap biaya. Setelah tanda dibuat, selanjutnya tetapkan rasio antar aktivitas dan cost component.

Penetapan rasio ini dapat menggunakan educated guess, systematic appraisal (AHP), dan actual data (Roztocki, 1999). Adapun penetapan rasio dalam penelitian ini menggunakan data aktual dan dugaan berbasis pengetahuan (educated guess) berdasarkan hasil brainstorming dengan pihak universitas, observasi langsung pada proses bisnis perguruan tinggi dilevel core dan support process serta analisis atas laporan keuangan universitas.

Langkah 6 - Menghubungkan Aktivitas dengan Produk melalui Matrik APD

Untuk menentukan hubungan biaya yang dikonsumsi aktivitas per produk, langkah awal yang dilakukan adalah membuat tanda centang (check-marks) yang diletakan secara proporsional untuk menentukan hubungan aktivitas dengan produk yang dihasilkan. Berdasarkan perhitungan pada matrik APD diketahui penyerapan institution overhead cost masing-masing program studi berdasarkan aktivitas. Selanjutnya dilakukan perhitungan total overhead cost yang diserap masing-masing program studi dengan menjumlahkan hasil driver tracing dengan perhitungan pada matrik APD sebagai berikut: 
Tabel 5. Penyerapan Overhead Cost masing-masing Program Studi Sumber : Hasil Pengolahan Data

\begin{tabular}{|c|c|c|c|c|}
\hline \multirow[b]{2}{*}{ Program Studi S1 } & \multicolumn{2}{|c|}{ Realisasi Overhead Cost } & \multirow[b]{2}{*}{$\begin{array}{l}\text { Total Overhead } \\
\text { Cost (Rp) }\end{array}$} & \multirow[b]{2}{*}{$\%$} \\
\hline & $\begin{array}{l}\text { Program Studi } \\
\text { (Rp) }\end{array}$ & $\begin{array}{l}\text { Universitas } \\
\quad(\mathrm{Rp})\end{array}$ & & \\
\hline S1 Agroteknologi & 31.944 .500 & 524.209 .493 & 556.153 .993 & $9 \%$ \\
\hline S1 Peternakan & 21.944 .500 & 392.901 .341 & 414.845 .841 & $7 \%$ \\
\hline S1 Manajemen & 202.350 .000 & 954.399 .398 & 1.156 .749 .398 & $19 \%$ \\
\hline S1 Pendidikan Biologi & 83.810 .000 & 706.823 .318 & 790.633 .318 & $13 \%$ \\
\hline S1 Pendidikan Bahasa Inggris & 20.949 .000 & 497.621 .211 & 518.570 .211 & $9 \%$ \\
\hline S1 Teknik Sipil & 189.970 .500 & 677.106 .243 & 867.076 .743 & $14 \%$ \\
\hline S1 Ilmu Hukum & 30.630 .000 & 571.234 .222 & 601.864 .222 & $10 \%$ \\
\hline S1 Ilmu Administrasi Negara & 375.320 .000 & 703.253 .055 & 1.078 .573 .055 & $18 \%$ \\
\hline Total & 956.918 .500 & 5.027 .548 .281 & 5.984 .466 .781 & $100 \%$ \\
\hline
\end{tabular}

\section{Perhitungan Distorsi Biaya Existing terhadap ABC}

Setelah dilakukan perhitungan biaya dengan metode $\mathrm{ABC}$, dapat dihitung distorsi biaya antara biaya existing terhadap hasil perhitungan $\mathrm{ABC}$. Hasil perhitungan biaya dengan menggunakan metode $\mathrm{ABC}$ diperoleh sebagai berikut :

Tabel 6. Total Biaya berdasarkan Activity Based Costing Sumber : Hasil Pengolahan Data

\begin{tabular}{lrrrrrr}
\hline \multicolumn{1}{c}{ Program Studi } & $\begin{array}{c}\text { Direct Labor } \\
\text { Cost }(\mathrm{Rp})\end{array}$ & $\begin{array}{c}\text { Material Cost } \\
(\mathrm{Rp})\end{array}$ & $\begin{array}{l}\text { Overhead } \\
\text { Cost }(\mathrm{Rp})\end{array}$ & $\begin{array}{c}\text { Total Cost } \\
(\mathrm{Rp})\end{array}$ & $\begin{array}{r}\text { Beban Pokok } \\
\text { (ABC) } 1\end{array}$ & $\begin{array}{c}\text { Beban } \\
\text { Pokok 1 } \\
\text { Smt Per } \\
\text { Mhs }\end{array}$ \\
\hline S1 Agroteknologi & 385.461 .810 & 115.284 .964 & 556.153 .993 & 1.056 .900 .767 & 528.450 .384 & 1.394 .328 \\
\hline S1 Peternakan & 219.707 .180 & 98.704 .036 & 414.845 .841 & 733.257 .057 & 366.628 .528 & 3.363 .564 \\
\hline S1 Manajemen & 739.701 .491 & 535.144 .000 & 1.156 .749 .398 & 2.431 .594 .889 & 1.215 .797 .444 & 846.066 \\
\hline S1 Pendidikan Biologi & 252.774 .400 & 340.040 .802 & 790.633 .318 & 1.383 .448 .520 & 691.724 .260 & 864.655 \\
\hline S1 Pend. Bhs. Inggris & 448.819 .200 & 165.042 .966 & 518.570 .211 & 1.132 .432 .377 & 566.216 .189 & 1.470 .691 \\
\hline S1 Teknik Sipil & 517.889 .945 & 164.049 .500 & 867.076 .743 & 1.549 .016 .188 & 774.508 .094 & 973.000 \\
\hline S1 Ilmu Hukum & 829.195 .776 & 101.622 .600 & 601.864 .222 & 1.532 .682 .598 & 766.341 .299 & 1.351 .572 \\
\hline S1 Ilmu Adm. Negara & 592.178 .547 & 251.995 .600 & 1.078 .573 .055 & 1.922 .747 .202 & 961.373 .600 & 1.125 .730 \\
\hline Total & 3.985 .728 .349 & 1.771 .884 .468 & 5.984 .466 .781 & 11.742 .079 .598 & 5.871 .039 .799 & 11.389 .608 \\
\hline
\end{tabular}

Berdasarkan perhitungan beban pokok penyelenggaraan pendidikan menggunakan Metode ABC, diketahui beban pokok per semester sebesar Rp. 5.871.039.799 dan beban pokok 1 semester per mahasiswa adalah sebesar Rp. 11.389.608. Hasil perhitungan ini selanjutnya dibandingkan dengan perhitungan biaya secara tradisional pada Tabel 7 sehingga selisih/variansi biaya dari metode exsisting (traditional costing) terhadap metode ABC adalah:

Tabel 7. Variansi Biaya Tradisional Costing terhadap ABC

Sumber : Hasil Pengolahan Data

\begin{tabular}{|c|c|c|c|c|c|c|c|c|}
\hline \multirow[t]{2}{*}{ Program Studi } & $\begin{array}{c}\text { Beban Pokok } \\
\text { Metode } \\
\text { Tradisional }\end{array}$ & $\begin{array}{c}\text { Beban Pokok } \\
\text { ABC }\end{array}$ & $\begin{array}{c}\text { Distorsi Per } \\
\text { SMT }\end{array}$ & \multirow[t]{2}{*}{$\%$} & $\begin{array}{c}\text { Beban } \\
\text { Pokok } \\
\text { Tradisional }\end{array}$ & $\begin{array}{c}\text { Beban } \\
\text { Pokok } \\
\text { ABC }\end{array}$ & $\begin{array}{c}\text { Distorsi Per } \\
\text { MHS }\end{array}$ & \multirow[t]{2}{*}{$\%$} \\
\hline & 1 Semester & 1 Semester & $\begin{array}{c}\text { Tradisional - } \\
\text { ABC }\end{array}$ & & $\begin{array}{c}1 \text { SMS Per } \\
\text { MHS }\end{array}$ & $\begin{array}{c}1 \text { SMS } \\
\text { Per MHS }\end{array}$ & $\begin{array}{l}\text { Tradisional } \\
\text { - ABC }\end{array}$ & \\
\hline S1 Agroteknologi & 445.193 .093 & 528.450 .384 & -83.257 .291 & $-15,75 \%$ & 1.174 .652 & 1.394 .783 & -219.676 & $-15,75 \%$ \\
\hline S1 Peternakan & 221.614 .198 & 366.628 .528 & -145.014 .331 & $-39,55 \%$ & 2.033 .158 & 3.363 .564 & -1.330 .407 & $-39,55 \%$ \\
\hline S1 Manajemen & 1.416 .708 .021 & 1.215 .797 .444 & 200.910 .577 & $16,53 \%$ & 985.879 & 846.066 & 139.813 & $16,53 \%$ \\
\hline $\begin{array}{l}\text { S1 Pendidikan } \\
\text { Biologi }\end{array}$ & 715.827 .020 & 691.724 .260 & 24.102 .761 & $3,48 \%$ & 894.784 & 868.655 & 30.128 & $3,48 \%$ \\
\hline $\begin{array}{l}\text { S1 Pend. Bhs. } \\
\text { Inggris }\end{array}$ & 499.084 .397 & 566.216 .189 & -67.131 .791 & $-11,86 \%$ & 1.296 .323 & 1.470 .691 & -174.368 & $-11,86 \%$ \\
\hline
\end{tabular}




\begin{tabular}{|c|c|c|c|c|c|c|c|c|}
\hline \multirow[t]{2}{*}{ Program Studi } & $\begin{array}{c}\text { Beban Pokok } \\
\text { Metode } \\
\text { Tradisional }\end{array}$ & $\begin{array}{c}\text { Beban Pokok } \\
\text { ABC }\end{array}$ & $\begin{array}{c}\text { Distorsi Per } \\
\text { SMT }\end{array}$ & \multirow[t]{2}{*}{$\%$} & $\begin{array}{c}\text { Beban } \\
\text { Pokok } \\
\text { Tradisional }\end{array}$ & $\begin{array}{c}\text { Beban } \\
\text { Pokok } \\
\text { ABC }\end{array}$ & $\begin{array}{c}\text { Distorsi Per } \\
\text { MHS }\end{array}$ & \multirow[t]{2}{*}{$\%$} \\
\hline & 1 Semester & 1 Semester & $\begin{array}{c}\text { Tradisional - } \\
\text { ABC } \\
\end{array}$ & & $\begin{array}{c}1 \text { SMS Per } \\
\text { MHS }\end{array}$ & $\begin{array}{c}1 \text { SMS } \\
\text { Per MHS }\end{array}$ & $\begin{array}{c}\text { Tradisional } \\
\text { - ABC }\end{array}$ & \\
\hline S1 Teknik Sipil & 811.581 .820 & 774.508 .094 & 37.073 .726 & $4,79 \%$ & 1.019 .575 & 973.000 & 46.575 & $4,79 \%$ \\
\hline S1 Ilmu Hukum & 748.287 .533 & 766.341 .299 & -18.053 .766 & $-2,36 \%$ & 1.319 .731 & 1.351 .572 & -31.841 & $-2,36 \%$ \\
\hline $\begin{array}{l}\text { S1 Ilmu Adm. } \\
\text { Negara }\end{array}$ & 1.012 .743 .716 & 961.373 .600 & 51.370 .115 & $5,34 \%$ & 1.185 .883 & 1.125 .730 & 60.152 & $5,34 \%$ \\
\hline
\end{tabular}

\section{Pembahasan}

Universitas Sintuwu Maroso sebagai sebuah institusi nirlaba harus dapat memastikan bahwa setiap jasa yang diberikan bagi mahasiswanya telah dikeluarkan dengan perhitungan biaya yang efisien. Selain itu, pihak manajemen juga harus mampu atau sedapat mungkin berusaha meminimumkan biaya yang dibutuhkan dalam melangsungkan kegiatan operasinya. Hal ini bertujuan untuk menyediakan nilai pelanggan yang sama (lebih besar) dengan biaya yang lebih rendah dari perguruan tinggi yang lain. Mengurangi biaya yang dibutuhkan untuk mencapai manfaat tertentu berarti perusahaan lebih efisien. Inilah yang ingin dicapai dengan melakukan analisis biaya menggunakan metode Activity Based Costing (ABC).

Analisis atas beban pokok yang dilakukan pihak manajemen Universitas Sintuwu Maroso selama ini dianggap memiliki tingkat akurasi yang rendah karena metode ini terlalu menyederhanakan proses bagaimana jasa pendidikan itu dihasilkan. Program studi yang berbeda-beda karakteristiknya diasumsikan hanya menggunakan satu cost driver berbasis unit sehingga biaya overhead yang terjadi dialokasikan ke masing-masing program studi hanya berdasarkan proporsi mahasiswa aktif sehingga hasil perhitungan beban pokok akan proporsional dengan volumenya. Padahal pada kenyataannya masing-masing program studi dalam memproduksi jasa bagi mahasiswa membutuhkan aktivitas yang tingkat konsumsi sumber dayanya akan berbeda-beda. Oleh karena itu, perhitungan beban pokok yang dilakukan selama ini dianggap tidak relevan dan memerlukan perubahan.

Pendapat tersebut sejalan dengan pernyataan Duron (2001) yang menyatakan bahwa manajemen biaya tradisional saat ini sudah tidak relevan lagi dengan perkembangan dan perubahan lingkungan organisasi pendidikan tinggi. Alokasi sumber daya dari perhitungan secara tradisional dianggap kurang tepat sehingga melemahkan peran informasi biaya dalam pengambilan keputusan suatu organisasi. Informasi yang dihasilkan dari perhitungan secara tradisional ini menghasilkan informasi biaya yang terdistorsi sehingga mengarahkan kebijakan penetapan biaya pendidikan yang tidak tepat. Biaya pendidikan untuk beberapa program studi seharusnya ditetapkan lebih tinggi dihargai terlalu murah, begitu pula sebaliknya.

Menerapkan metode $\mathrm{ABC}$ pada perguruan tinggi akan dapat meningkatkan kualitas informasi biaya untuk analisis keuangan pada perguruan tinggi. Selain itu akan dapat terlihat bahwa tidak semua biaya-biaya terutama biaya overhead berkorelasi proporsional dengan besarnya volume produk. Hasil dari penerapan metode $\mathrm{ABC}$ pada perguruan tinggi dapat pula digunakan sebagai dasar dalam penganggaran, evaluasi kinerja, penilaian efektifitas program dan keputusan penetapan biaya di perguruan tinggi. Metode ABC juga dipandang mampu dan lebih baik dalam pengalokasian sumber daya serta pengetatan manajemen keuangan dan dapat digunakan sebagai suatu sistem pendukung keputusan (decision support system) (Ismail, 2010).

Penerapan metode $\mathrm{ABC}$ yang dilakukan dalam penelitian ini mendeteksi adanya distorsi biaya apabila dibandingkan dengan metode tradisional (existing) sebagaimana ditunjukan pada Tabel 
7. Distrosi biaya ini adalah terjadinya over dan under costing beban pokok program studi di Universitas Sintuwu Maroso pada Tahun 2018-2019 dengan rincian sebagai berikut:

1. Program Studi Agroteknologi terdeteksi under costing sebesar Rp. 219.676 atau sebesar $15,75 \%$.

2. Program Studi Peternakan terdeteksi mengalami under costing paling besar yaitu sebesar Rp. 1.330.407 atau 39,55\%. Hal ini disebabkan jumlah mahasiswa Program Studi Peternakan yang hanya sebanyak 109 orang, sementara biaya operasional pendidikan yang diserap mencapai Rp. 733.257.057.

3. Program Studi Manajemen sebagai prodi dengan jumlah mahasiswa aktif paling banyak terdeteksi mengalami over costing sebesar Rp. 139.813 atau 16,53\%.

4. Program Studi Pendidikan Biologi terdeteksi mengalami over costing sebesar Rp. 30.128 atau $3,48 \%$.

5. Program Studi Pendidikan Bahasa Inggris terdeteksi mengalami under costing sebesar Rp. 174.368 atau $11,86 \%$.

6. Program Studi Teknik Sipil terdeteksi mengalami over costing sebesar Rp.46.575 atau 4,79\%.

7. Program Studi Ilmu Hukum terdeteksi mengalami under costing sebesar Rp.31.841 atau $2,36 \%$.

8. Program Studi Ilmu Administrasi Negara mengalami over costing sebesar Rp.60.152 atau $5,34 \%$.

Hasil penelitian menunjukkan bahwa satu program studi kelompok non-eksakta (Ilmu Hukum) dan sebagian besar program studi kelompok eksakta (Agroteknologi, Peternakan, Pendidikan Biologi) mengalami under costing yang berarti selama biaya pendidikan yang dibayarkan oleh mahasiswa masih sedikit daripada jumlah yang seharusnya dibebankan, sedangkan sebaliknya bagi program studi yang mengalami over costing berarti bahwa selama ini mahasiswa membayar biaya pendidikan lebih mahal daripada yang seharusnya dibebankan. Hansen \& Mowen, (2004) menjelaskan timbulnya distorsi adalah ketidakakuratan dalam pembebanan biaya, sehingga mengakibatkan kesalahan dalam penentuan biaya, pembuatan keputusan, perencanaan dan pengendalian.

Berdasarkan hasil analisis yang diperoleh dari perhitungan beban pokok menggunakan metode ABC, beberapa program studi yang mengalami under costing setelah dianalisis dengan menggunakan metode $\mathrm{ABC}$ ternyata memiliki profitabilitas yang lebih rendah dibandingkan dengan menggunakan metode tradisional. Artinya bahwa penyelenggaraan beberapa program studi ini tanpa disadari memberikan kerugian bagi universitas. Selain itu distorsi biaya yang tedeteksi ini mengakibatkan ketidakseimbangan pada penganggaran perguruan tinggi selama ini dimana beberapa program kerja utama seperti peningkatan fasilitas pembelajaran tertunda dikarenakan kondisi keuangan yang tidak mencukupi.

Hasil analisis yang telah dilakukan dalam penelitian ini menunjukkan bahwa penerapan metode ABC dapat meningkatkan keakuratan perhitungan beban pokok penyelenggaraan pendidikan di Universitas Sintuwu Maroso dibandingkan dengan metode tradisional dengan terdeteksinya distorsi/variansi biaya (over/under costing) pada seluruh program studi. Artinya bahwa metode ABC telah mampu diimplementasikan pada perusahaan jasa atau dalam hal ini institusi pendidikan tinggi dengan mengalokasikan biaya aktivitas ke setiap program studi secara tepat berdasarkan konsumsi masing-masing aktivitas. Dengan demikian Universitas Sintuwu Maroso disarankan meninjau ulang sistem perhitungan beban pokok yang selama ini digunakan dan mulai mempertimbangkan untuk menggunakan kalkulasi dengan metode Activity Based Costing 
sebagai salah satu analisis pertimbangan dalam penentuan biaya pendidikan pada masing-masing program studi di masa yang akan datang.

\section{KESIMPULAN DAN SARAN}

Berdasarkan penelitian yang telah dilakukan dapat disimpulkan bahwa beban pokok penyelenggaraan pendidikan tahun 2018-2019 di Universitas Sintuwu Maroso berdasarkan metode ABC per semester adalah sebesar Rp.5.871.039. Implementasi ABC dianggap berhasil meningkatkan keakuratan perhitungan beban pokok pada semua program studi di Universitas Sintuwu Maroso dibandingkan dengan metode traditional costing yang selama ini digunakan dengan terdeteksinya distorsi biaya (over/under costing).

Penerapan $\mathrm{ABC}$ dapat membantu pihak manajemen untuk memahami apa yang menyebabkan biaya-biaya (direct dan overhead) meningkat atau menurun dengan melakukan penelusuran ke masing-masing program studi. Hubungan sebab akibat ini memungkinkan pihak manajemen universitas untuk memperbaiki ketepatan perhitungan beban pokok, yang secara signifikan memperbaiki pengambilan keputusan.

\section{REFERENSI}

Binawati, L. (2011). Penerapan Activity Based Costing Untuk Meningkatkan Keakuratan Perhitungan Beban Pokok Program Studi Perguruan Tinggi X. Seminar Nasional Sistem \& Teknologi Informasi (SNASTI) 2011 (pp. 1-10). Surabaya: STIKOM Surabaya. Retrieved April 24, 2018, from sir.stikom.edu/id/eprint/488

Cooper, R. \& Kaplan, R.S. 1991. The Design of Cost Management System: Text, Cases, and Readings, Englewood Cliff, NJ: Pentice Hall Inc

Duron, Robert W, 2001, Factors Associated with the perceive benefit of ABC in non profit institution of higher educations, Dissertation, Capella University.

Esti, D. (2007). Pengembangan. Sumber-sumber Pendapatan Perguruan Tinggi. Jurnal Manajemen Pendidikan, 3(2).

Hansen, D. R., \& Mowen, M. M. (2004). Management Accounting, 7th. (T. P. Salemba, Trans.) Jakarta: Salemba Empat

Ismail, N. A. (2010). Activity-based management system implementation in higher education institution benefits and challenges. Jurnal Campus-wide Information Systems, 40-52. Retrieved Mei 3, 2018, from www.emeraldinsight.com/1065-0741.htm.

Islahuzzaman. (2011). Activity-Based Costing: Teori dan Aplikasi. Bandung: Penerbit Alfabeta

Krishnan, Anbalagan. (2006) An Application of Activity Based Costing in Higher Learning Institution: A Local Case Study, Jurnal of Contemporary Management Research / CMR Vol 2, No 2

PDDIKTI Kemdikbud. (2020, 8 19). Pangkalan Data Pendidikan Tinggi. Retrieved from https://pddikti.kemdikbud.go.id/pt

Mahani, A., \& Nasution, A. (2008). Perancangan Model Activity Based Costing Untuk Menentukan Standar Unit Cost Pendidikan Program S-1 (Studi Kasus: Jurusan Statistik ITS). Student Journal ITS.

Mulyadi. (2007). Activity Based Costing System. Yogyakarta: UPP STIM YKPN.

Nazir, Moh. (2005). Metode Penelitian. Bogor: Ghalia Indonesia.

O'Guin, M. C. (1991). Activity-Based Costing for Information Systems. Journal of Cost Management, Spring, pp. 35-39.

Roztocki, N. Valenzuela, J., Porter, J., Monk, M.R., dan Needy, K.L.S., (1999). A Procedure for Smooth Implementation of Activity Based Costing in Small Companies. Retrieved from http://www2.newpaltz.edu/ roztockn/virginia99.pdf/. 